\title{
ANALISIS ATAS PENERAPAN PAJAK PENGHASILAN PASAL 22 (PENGADAAN BARANG) PADA PT. DANA TABUNGAN DAN ASURANSI PEGAWAI NEGERI (PERSERO) KANTOR CABANG MANADO
}

\author{
Wulandari Safitri Bawon ${ }^{1}$, Jantje J. Tinangon ${ }^{2}$, Steven Tangkuman ${ }^{3}$ \\ ${ }^{1,2,3}$ Jurusan Akuntansi, Fakultas Ekonomi dan Bisnis, Universitas Sam Ratulangi, Jl. Kampus Bahu, Manado, \\ 95115, Indonesia
}

E-mail : wulandarisafitribawon@gmail.com

\begin{abstract}
This study aims to determine the application of Income Tax Article 22 to Companies Savings Funds and Insurance of Employee Staff Manado Branch Office and find out whether the application has been in accordance with Regulation of the Minister of Finance No. 34 / PMK.010 / 2017. The type of research used is qualitative research using descriptive analysis technique. The results showed that the calculation used a tariff of $1.5 \%$ and paid using electronic SSP to the perception bank appointed by the Minister of Finance. And reporting is done using manual SPT and report it to Tax Office. The calculation, deposits, and reporting of Income Tax Article 22 is not fully in accordance with Regulation of the Minister of Finance No. 34 / PMK.010 / 2017 due to negligence in accounting that resulted in overpayment, and from the company does not issue Tax Assessment Letter More Pay (SKPLB) for SPT correction.
\end{abstract}

Keywords : income tax, procurement, calculation, deposits, reporting

\section{PENDAHULUAN}

Indonesia adalah negara dengan tingkat populasi tertinggi ketiga yang mempunyai beragam budaya dan sumber daya alam yang melimpah. Perkembangan yang terjadi saat ini, membuat pemerintah berupaya untuk melakukan perubahan di segala sektor untuk meningkatkan penerimaan negara guna membiayai pembangunan semata-mata untuk kepentingan rakyat. Terciptanya kesejahteraan dan kemakmuran rakyat secara adil, pemerintah harus melakukan pembangunan yang merata di seluruh wilayah Indonesia. Sumber dana dari pemerintah untuk melakukan pembangunan tersebut didapatkan dari beberapa sektor, baik itu penerimaan dari sektor pajak maupun penerimaan negara bukan sektor pajak seperti migas dan non migas.

Pajak adalah alternatif yang sangat potensial dalam menunjang perekonomian negara. Sektor pajak adalah pilihan yang tepat, karena merupakan penerimaan terbesar negara. $\mathrm{PPh}$ adalah salah satu jenis pajak yang mempunyai peranan cukup besar dalam sektor pajak, baik itu diperoleh dari pendapatan perorangan, atau pendapatan suatu entitas. PPh yang ditetapkan oleh pemerintah pun ada berbagai macam salah satunya adalah $\mathrm{PPh}$ Pasal 22. dimana pihak ketiga adalah sebagai pemungut pajak. Berdasarkan pada Peraturan Menteri Keuangan Nomor 34/PMK.010/2017 yang menggantikan peraturan sebelumnya yaitu Peraturan Menteri Keuangan nomor 16/PMK.010/2016 salah satu pemungut pajak Penghasilan Pasal 22 adalah Badan Usaha Milik Negara (BUMN). PT Dana Tabungan dan Asuransi Pegawai Negeri (Persero) adalah salah satu Badan Usaha Milik Negara (BUMN) yang dipercayakan oleh pemerintah untuk mengelola Dana Asuransi dan Tabungan Hari Tua Pegawai Negeri sipil.

Untuk terciptanya kenyamanan dalam pelayanan, tentu tidak terlepas dari pembelian barang-barang atau alat-alat yang menunjang pelayanan kepada penerima pensiunan. Beberapa barang yang dibeli oleh perusahaan terdapat pengenaan Pajak Penghasilan Pasal 22. Sebagai perusahaan yang taat akan aturan pajak, maka setiap kegiatan yang ada hubungannya dengan pengadaan barang wajib dikenakan pajak sesuai dengan peraturan yang berlaku. 
Maka dari itu, wajib pajak harus melakukan perhitungan, penyetoran, dan pelaporan utang pajak PPh Pasal 22 ke KPP dimana perusahaan tersebut telah di kukuhkan sebagai Pengusaha Kena Pajak (PKP).

\section{TINJAUAN PUSTAKA}

\subsection{Definisi Akuntansi}

Akuntansi merupakan suatu bentuk kegiatan untuk memberikan suatu informasi tentang perhitungan, dengan tujuan untuk pengambilan keputusan suatu entitas tentang pilihan-pilihan yang logis dan beragam tindakan alternatif dari penyajian informasi keuangan tersebut.(Skousen, dikutip dalam Setiawan 2014 : 4).

\subsection{Definisi Akuntansi Pajak}

Akuntansi pajak merupakan bagian dalam akuntansi yang timbul dari unsur spesialisasi yang menuntut keahlian dalam bidang tertentu. (Waluyo, $2016: 2$ ).

\subsection{Konsep Pajak}

\subsubsection{Definisi Pajak}

Menurut Undang-Undang No. 16 Tahun 2009, pajak yaitu suatu kontribusi wajib dari wajib pajak baik perorangan maupun badan kepada negara yang bersifat memaksa berdasarkan Undang-undang.

\subsubsection{Fungsi Pajak}

1. Fungsi Budgeter

Pajak memiliki fungsi budgeter karena pajak adalah salah satu pendapatan negara yang diperuntukkan untuk pembiayaan rutin pemerintah, misalnya dimasukkannya pajak dalam APBN sebagai penerimaan dalam negeri.

2. Fungsi Mengatur (Reguler)

Pajak mempunyai fungsi mengatur karena pajak sebagai alat pengatur dan pelaksanaan kebijakan baik sosial maupun ekonomi, untuk mencapai tujuan tertentu diluar bidang keuangan.

\subsubsection{Pengertian Pajak Penghasilan Pasal 22}

Menurut UU PPh Nomor 36 tahun 2008, PPh Pasal 22 adalah suatu bentuk potongan atau pungutan pajak yang dilakukan oleh satu pihak tertentu terhadap pihak lain yang berkaitan dengan pengadaan barang.

\subsubsection{Pengertian Perhitungan, Penyetoran, dan Pelaporan Pajak}

Perhitungan pajak adalah perhitungan pajak terutang dengan cara mengalikan tarif pajak dengan dasar pengenaan pajaknya sehingga diperoleh jumlah pajak yang terutang. Penyetoran pajak adalah kegiatan membayar pajak terutang yang dilakukan sendiri oleh wajib pajak ke kantor pos atau bank yang ditunjuk oleh Menteri Keuangan. pelaporan pajak ialah penyampaian dari hasil perhitungan dan penyetoran ke kas negara dengan menggunakan surat pemberitahuan yang telah ditentukan. (Nugraha, Prastowo, dan Priyatna, 2014 : 52).

\subsubsection{Tarif Pajak Penghasilan Pasal 22}

Atas pembelian barang dan / atau bahan-bahan untuk keperluan kegiatan usaha adalah sebesar 1,5\% untuk Wajib Pajak yang mempunyai NPWP, dan 3\% untuk Wajib Pajak yang tidak mempunyai NPWP.

\subsubsection{Prosedur Pemungutan dan Penyetoran Pajak Penghasilan Pasal 22}

1. Pajak Penghasilan Pasal 22 yang dipungut oleh pemungut pajak harus dibayarkan oleh pihak yang memungut, dalam hal ini bendaharawan pemerintah ke KPP terdaftar melalui pos atau bank persepsi yang sudah ditunjuk oleh Menteri Keuangan dengan menggunakan SSP yang sudah diberikan nama rekanan serta terdapat tanda tangan yang dilakukan oleh pihak yang memungut pajak dan Bukti Penerimaan Negara yang sudah diberikan nama rekanan. 
2. $\mathrm{PPh}$ Pasal 22 yang dipungut oleh pihak yang memungut pajak harus disetor oleh pemungut ke kas Negara melalui pos atau bank persepsi yang sudah yang sudah ditunjuk oleh Menteri Keuangan

3. Bukti pemungutan $\mathrm{PPh}$ Pasal 22 wajib diterbitkan oleh pemungut

4. Jangka waktu penyetoran dan pelaporan PPh Pasal 22 ditetapkan oleh Menteri Keuangan, sehingga wajib pajak harus menyetor dan melapor utang PPh Pasal 22 sesuai dengan jangka waktu yang sudah diteteapkan.

\subsubsection{Peraturan Menteri Keuangan Pasal 2 PMK-242/PMK.03/2014 dan Pasal 10 nomor 11 PMK-243/PMK.03/2014}

Menurut Peraturan Menteri Keuangan Pasal 2 PMK-242/PMK.03/2014 tentang batas

akhir penyetoran Pajak Penghasilan Pasal 22 kepada bendaharawan pemerintah adalah tanggal 10 (sepuluh) bulan berikutnya setelah masa pajak berakhir dan Peraturan Menteri Keuangan Pasal 10 nomor 11 PMK-243/PMK.03/2014 tentang pelaporan Pajak Penghasilan Pasal 22 adalah paling lama 20 hari setelah masa pajak berakhir.

\section{METODE PENELITIAN}

\subsection{Jenis Penelitian}

Penelitian dilaksanakan dengan cara menggambarkan proses perhitungan, penyetoran dan PPh Pasal 22. Untuk mengevaluasi ketepatan penerapan Pajak Penghasilan Pasal 22, penelitian ini dilakukan dengan mengumpulkan data-data yang diperlukan seperti bukti transaksi dan bukti pungut serta kemudian menguraikannya secara keseluruhan.

\subsection{Tempat dan Waktu Penelitian}

Penelitian dilaksanakan di PT. Dana Tabungan dan Asuransi Pegawai Negeri (Persero) Kantor Cabang Manado bertempat di Jl. Ahmad Yani no.7 Manado Sulawesi Utara. Waktu penelitian dimulai pada bulan April 2018 hingga Mei 2018.

\subsection{Prosedur Penelitian}

Proses identifikasi permasalahan, melakukan pembatasan masalah, menetapkan fokus masalah, melaksanakan penelitian, mengolah dan menganalisis data, pemunculan teori, dan melaporkan hasil penelitian.

\subsection{Sumber Data}

Sumber data terdiri atas dua. Yaitu :

1. Data Primer. Yaitu data yang diperoleh secara langsung dari sumber asli dan dikumpulkan sendiri oleh peneliti.

2. Data Sekunder. Yaitu data yang dikumpulkan oleh orang lain, bukan peneliti itu sendiri.

Pada penelitian ini, menggunakan data primer dan data sekunder. Data primer yaitu data berupa hasil wawancara langsung penulis dengan beberapa pihak yang terkait. Seperti bendahara keuangan atau kepala bidang keuangan. Dan data sekunder berupa salinan perhitungan dan pelaporan serta bukti pungut Pajak Penghasilan Pasal 22.

\subsection{Teknik Pengumpulan Data} berikut.

Pengumpulan data yang digunakan dalam penelitian ini menggunakan teknik sebagai

1. Teknik wawancara. Yakni dengan dilakukannya proses tanya jawab yang berlangsung secara lisan kepada pihak-pihak narasumber. Seperti kepada bendahara perusahaan.

2. Teknik observasi. Yakni tekni untuk mengumpulkan data lewat pengamatan yang dilakukan pada objek studi penelitian.

3. Studi dokumentasi. Yakni melalui salinan data dan pencatatan seperti Salinan perhitungan dan pelaporan serta bukti pungut Pajak Penghasilan Pasal 22.

\subsection{Teknik Analisis Data}

Analisis data dilakukan dengan cara mengumpulkan, menyajikan, dan menganalisis data sehingga diperoleh gambaran yang cukup jelas mengenai permasalahan yang diangkat 
dengan melakukan perbandingan-perbandingan antara teori-teori dengan kenyataan yang terjadi dilapangan.

\section{HASIL ANALISIS DAN PEMBAHASAN}

\subsection{Hasil Analisis}

4.1.1. Analisis Perhitungan Pajak Penghasilan Pasal 22 Pada PT. Dana Tabungan dan Asuransi Pegawai Negeri (Persero) Kantor Cabang Manado

Melalui with holding system, perhitungan, penyetoran dan pelaporan dilakukan sendiri oleh oleh pihak ketiga yang memungut Pajak Penghasilan Pasal 22 yakni bendaharawan PT Dana Tabungan dan Asuransi Pegawai Negeri (Persero) KC Manado. Sehingga dalam mempertanggung jawabkan kewajiban perpajakannya, maka dari pihak bendahara PT Dana Tabungan dan Asuransi Pegawai Negeri (Persero) KC Manado harus serta merta mengisi segala data yang berhubungan dengan Pajak Penghasilan Pasal 22 dengan benar, lengkap, dan jelas. Berikut adalah tatacara perhitungan $\mathrm{PPh}$ Pasal 22 tentang pengadaan barang.

PPh Pasal 22 = 1,5\% x Harga Pembelian(Belum dipotong PPN)

Berikut tabel perhitungan Pajak Penghasilan Pasal 22 yang dilakukan oleh PT Dana Tabungan dan Asuransi Pegawai Negeri (Persero) Kantor Cabang Manado.

Tabel 4.1 Perhitungan Pajak Penghasilan Pasal 22 PT Dana Tabungan dan Asuransi Pegawai Negeri (Persero) Kantor Cabang Manado

\begin{tabular}{|l|l|r|r|r|}
\hline $\begin{array}{c}\text { Masa } \\
\text { Pajak }\end{array}$ & $\begin{array}{c}\text { Objek PPh } \\
\text { Pasal 22 }\end{array}$ & $\begin{array}{r}\text { DPP (Dasar } \\
\text { Pengenaan Pajak) }\end{array}$ & Tarif & $\begin{array}{c}\text { PPh yang } \\
\text { Dipungut }\end{array}$ \\
\hline Januari 2017 & Pengadaan Toner Printer & Rp. 13.950.000 & $3 \%$ & Rp. 418.500 \\
\hline Januari 2017 & Pengadaan Mobil dinas & Rp. 172.090.909 & $2 \%$ & Rp. 2.581.364 \\
\hline Februari 2017 & Pengadaan Kursi Lipat & Rp. 49.000.000 & $1,5 \%$ & Rp. 735.000 \\
\hline Februari 2017 & Pengadaan Petugas Alih Daya & Rp. 4.623.882 & $1,5 \%$ & Rp. 92.478 \\
\hline Maret 2017 & Pengadaan Kursi Lipat & Rp. 16.055.000 & $1,5 \%$ & Rp. 240.825 \\
\hline Maret 2017 & Pengadaan Kursi Lipat & Rp. 66.675.637 & $1,5 \%$ & Rp. 1.000 .134 \\
\hline April 2017 & Pengadaan Multimedia & Rp. 20.792.450 & $1,5 \%$ & Rp. 311.887 \\
\hline April 2017 & Pengadaan Notebook & Rp. 25.760.000 & $1,5 \%$ & Rp. 386.400 \\
\hline Agustus 2017 & Pengadaan Tintadan Toner & Rp. 28.946.445 & $1,5 \%$ & Rp. 434.197 \\
\hline Jumlah & & Rp. 387.894.323 & & Rp. 6.200.785 \\
\hline
\end{tabular}

Sumber : PT Dana Tabungan dan Asuransi Pegawai Negeri (Persero) KC Manado

Pada tabel diatas, menunjukkan bahwa pemungutan Pajak Penghasilan Pasal 22 terjadi pada bulan Januari, Februari, Maret, April, dan Agustus yang dimana tidak hanya terdapat tarif $1,5 \%$ yang dilakukan pihak perusahaan, akan tetapi juga terdapat beberapa tarif, seperti 3\% dan 2\%. Dari hasil wawancara yang dilakukan oleh bendaharawan PT Dana Tabungan dan Asuransi Pegawai Negeri (Persero) Kantor Cabang Manado, tarif 3\% yang terdapat pada bulan Januari adalah karena pihak rekanan tidak mempunyai NPWP atau tidak dikukuhkan sebagai Pengusaha Kena Pajak maka dari itu dikenakan tarif 100\% lebih tinggi dari pada tarif yang diterapkan terhadap Wajib Pajak yang mempunyai NPWP. Sehingga untuk pengenaan tarif 3\% telah sesuai dengan aturan yang berlaku yaitu PMK No 34/PMK.010/2017. Jadi, pada bulan Januari atas pengadaan toner printer, pihak bendaharawan perusahaan memungut pajak sebesar Rp. 418.500. Pada bulan Januari yakni transaksi pengadaan mobil dinas terdapat kesalahan penulisan pada tarif, yang seharusnya adalah $1,5 \%$, menjadi $2 \%$. Namun untuk hasil perhitungan adalah benar yakni menggunakan tarif 1,5\% dengan hasil perhitungan sebesar Rp. 2.581.364. selanjutnya pada bulan Februari yakni transaksi pengadaan Petugas Alih Daya adalah kekeliruan dari bagian umum perusahaan yang salah menginput akun. Karena transaksi tersebut merupakan transaksi 
dibidang pengadaan jasa, maka seharusnya dikenakan Pajak Penghasilan Pasal 23 dengan tarif 2\% dengan pemungutan yang dipisahkan dari pemungutan Pajak Penghasilan Pasal 22.

Tabel berikut akan menampilkan hasil olahan dari peneliti atas pengadaan barang yang dilakukan oleh PT Dana Tabungan dan Asuransi Pegawai Negeri (Persero) Kantor Cabang Manado dengan menggunakan dasar Peraturan Pajak yakni Peraturan Menteri Keuangan Republik Indonesia Nomor 34/PMK.010/2017.

Tabel 4.2 Perhitungan Pajak Penghasilan Pasal 22 PT Dana Tabungan dan Asuransi Pegawai Negeri (Persero) Kantor Cabang Manado Data Olahan

\begin{tabular}{|l|l|r|r|r|}
\hline $\begin{array}{c}\text { Masa } \\
\text { Pajak }\end{array}$ & $\begin{array}{c}\text { Objek PPh } \\
\text { Pasal 22 }\end{array}$ & $\begin{array}{c}\text { DPP(Dasar } \\
\text { Pengenaan Pajak) }\end{array}$ & Tarif & \multicolumn{1}{c|}{$\begin{array}{c}\text { PPh yang } \\
\text { Dipungut }\end{array}$} \\
\hline Januari 2017 & Pengadaan Toner Printer & Rp. 13.950.000 & $3 \%$ & Rp. 418.500 \\
\hline Januari 2017 & Pengadaan Mobil dinas & Rp. 172.090.909 & $1,5 \%$ & Rp. 2581.364 \\
\hline Februari 2017 & Pengadaan Kursi Lipat & Rp. 49.000.000 & $1,5 \%$ & Rp. 735.000 \\
\hline Maret 2017 & Pengadaan Kursi Lipat & Rp. 16.055.000 & $1,5 \%$ & Rp. 240.825 \\
\hline Maret 2017 & Pengadaan Kursi Lipat & Rp. 66.675.637 & $1,5 \%$ & Rp. 1.000 .134 \\
\hline April 2017 & Pengadaan Multimedia & Rp. 20.792.450 & $1,5 \%$ & Rp. 311.887 \\
\hline April 2017 & Pengadaan Notebook & Rp. 25.760.000 & $1,5 \%$ & Rp. 386.400 \\
\hline Agustus 2017 & Pengadaan Tinta dan Toner & Rp. 28.946.445 & $1,5 \%$ & Rp. 434.197 \\
\hline Jumlah & & Rp. 383.270.441 & & Rp. 6.108.307 \\
\hline
\end{tabular}

Sumber : Data Sekunder yang diolah peneliti

Dari hasil olahan data perhitungan Pajak Penghasilan Pasal 22 atas pengadaan barang oleh PT Dana Tabungan dan Asuransi Pegawai Negeri (Persero) Kantor Cabang Manado, untuk transaksi Pengadaan Mobil dinas sudah diganti menjadi 1,5\% dengan total yang sama sebelumnya, dan pada transaksi pengadaan Petugas Alih Daya dengan pada bulan januari telah hapuskan. Dengan demikian total jumlah Pajak Penghasilan yang dipungut oleh perusahaan adalah sebesar Rp 6.108.307 dengan Dasar Pengenaan Pajak (DPP) sebesar Rp. 383.270.441.

4.1.2. Analisis Penyetoran Pajak Penghasilan Pasal 22 Pada PT. Dana Tabungan dan Asuransi Pegawai Negeri (Persero) Kantor Cabang Manado

Tabel berikut akan menampilkan penyetoran Pajak Penghasilan Pasal 22 oleh PT Dana Tabungan dan Asuransi Pegawai Negeri (Persero).

Tabel 4.3 Penyetoran Pajak Penghasilan Pasal 22 PT Dana Tabungan dan Asuransi Pegawai Negeri Kantor Cabang Manado (Persero)

\begin{tabular}{|l|r|l|l|}
\hline Masa Pajak & $\begin{array}{c}\text { PPh Pasal 22 Tarif } \\
(\mathbf{1 , 5 \% )}\end{array}$ & \multicolumn{1}{|c|}{$\begin{array}{c}\text { Tanggal } \\
\text { Penyetoran }\end{array}$} & Keterangan \\
\hline Januari 2017 & Rp. 2.999.864 & 09 Februari 2017 & Tidak Terlambat \\
\hline Februari 2017 & Rp. 827.478 & 10 Maret 2017 & Tidak Terlambat \\
\hline Maret 2017 & Rp. 1.240.959 & 07 April 2017 & Tidak Terlambat \\
\hline April 2017 & Rp. 698.287 & 09 Mei 2017 & Tidak Terlambat \\
\hline Mei 2017 & - & - & Tidak Terjadi Transaksi \\
\hline Juni 2017 & - & - & Tidak Terjadi Transaksi \\
\hline Juli 2017 & - & - & Tidak Terjadi Transaksi \\
\hline Agustus 2017 & Rp. 434.197 & 07 September 2017 & Tidak Terlambat \\
\hline September 2017 & - & - & Tidak Terjadi Transaksi \\
\hline Oktober 2017 & - & - & Tidak Terjadi Transaksi \\
\hline November 2017 & - & - & Tidak Terjadi Transaksi \\
\hline Desember 2017 & - & - & Tidak Terjadi Transaksi \\
\hline
\end{tabular}

Sumber : PT Dana Tabungan dan Asuransi Pegawai Negeri (Persero) KC Manado (olahan) 
Pada tabel diatas, menunjukkan bahwa proses penyetorannya dalam bulan-bulan yang terdapat pemungutan Pajak Penghasilan Pasal 22, PT Dana Tabungan dan Asuransi Pegawai Negeri (Persero) Kantor Cabang Manado selaku pihak yang memungut Pajak Penghasilan Pasal 22 telah menyetorkan pajak terutangnya dengan tepat waktu sesuai dengan peraturan perpajakan yang berlaku. Hal ini dapat dilihat dari tanggal penyetoran yang tidak melebihi tanggal 10 bulan berikutnya, serta dengan jumlah yang sesuai dengan hasil perhitungan yang sudah dilakukan sebelumnya. Namun, untuk kesalahan penginputan transaksi pada masa pajak bulan Februari, yakni pada transaksi pengadaan Petugas Alih Daya tetap dibayarkan oleh pihak perusahaan. Sehingga terjadi lebih bayar dan harus dilakukan prosedur penerbitan Surat Ketetapan Pajak Lebih Bayar (SKPLB) oleh bendahara perusahaan.

4.1.3. Analisis Pelaporan Pajak Penghasilan Pasal 22 Pada PT Dana Tabungan dan Asuransi Pegawai Negeri (Persero) Kantor Cabang Manado

Berikutnya setelah masa pajak berakhir. Dan tabel berikut akan menampilkan pelaporan Pajak Penghasilan Pasal 22 oleh PT Dana Tabungan dan Asuransi Pegawai Negeri (Persero).

Tabel 4.4 Pelaporan Pajak Penghasilan Pasal 22 PT Dana Tabungan dan Asuransi Pegawai Negeri Kantor Cabang Manado (Persero)

\begin{tabular}{|l|r|l|l|}
\hline \multicolumn{1}{|c|}{ Masa Pajak } & $\begin{array}{c}\text { PPh Pasal 22 } \\
\text { Tarif (1,5\%) }\end{array}$ & \multicolumn{1}{c|}{$\begin{array}{c}\text { Tanggal } \\
\text { Pelaporan }\end{array}$} & Keterangan \\
\hline Januari 2017 & Rp. 2.999.864 & 13 Februari 2017 & Tidak Terlambat \\
\hline Februari 2017 & Rp. 827.478 & 15 Maret 2017 & Tidak Terlambat \\
\hline Maret 2017 & Rp. 1.240.959 & 13 April 2017 & Tidak Terlambat \\
\hline April 2017 & Rp. 698.287 & 17 Mei 2017 & Tidak Terlambat \\
\hline Mei 2017 & - & - & Tidak Terjadi Transaksi \\
\hline Juni 2017 & - & - & Tidak Terjadi Transaksi \\
\hline Juli 2017 & - & - & Tidak Terjadi Transaksi \\
\hline Agustus 2017 & Rp. 434.197 & 18 September 2017 & Tidak Terlambat \\
\hline September 2017 & - & - & Tidak Terjadi Transaksi \\
\hline Oktober 2017 & - & - & Tidak Terjadi Transaksi \\
\hline November 2017 & - & - & Tidak Terjadi Transaksi \\
\hline Desember 2017 & - & - & Tidak Terjadi Transaksi \\
\hline
\end{tabular}

Pada tabel diatas, menunjukkan bahwa proses pelaporannya dalam bulan-bulan yang terdapat pemungutan Pajak Penghasilan Pasal 22, PT Dana Tabungan dan Asuransi Pegawai Negeri (Persero) Kantor Cabang Manado selaku pihak yang memungut Pajak Penghasilan Pasal 22 telah melaporkan pajak terutangnya dengan tepat waktu sesuai dengan peraturan perpajakan yang berlaku. Hal ini dapat dilihat dari tanggal penyetoran yang tidak melebihi tanggal 20 bulan berikutnya, serta dengan jumlah yang sesuai dengan hasil perhitungan yang sudah dilakukan sebelumnya. Namun pihak perusahaan tidak melakukan pembetulan SPT yang terjadi pada awal penginputan.

\subsection{Hasil Pembahasan}

\subsubsection{Perhitungan Pajak Penghasilan Pasal 22}

PT Dana Tabungan dan Asuransi Pegawai Negeri (Persero) Kantor Cabang Manado selaku BUMN yang ditunjuk pemerintah dalam memungut Pajak Penghasilan Pasal 22 atas setiap transaksi pengadaan barang sesuai dengan Peraturan Menteri Keuangan Republik Indonesia Nomor 34/PMK.010/2017 yaitu dengan harga pembelian barang diatas Rp. 2.000.000 (dua juta rupiah) tidak termasuk PPN/PPNBM dan bukan jumlah yang dipecahpecah. Bagi penyedia yang menjadi rekanan yaitu pengusaha yang sudah dikukuhkan menjadi Pengusaha Kena Pajak akan dikenakan tarif 1,5\% dari Dasar Pengenaan Pajak yaitu harga 
beli sebelum kena PPN/PPNBM dan 3\% bagi pengusaha yang tidak dikukuhkan menjadi Pengusaha Kena Pajak, atau tidak memiliki NPWP sehingga dalam pemberian tarif yang dilakukan oleh bendahara PT Dana Tabungan dan Asuransi Pegawai Negeri (Persero) Kantor Cabang Manado telah sesuai dengan peraturan perpajakan yang berlaku. Adapun Perhitungan utang pajak yang dilakukan oleh bendahara perusahaan PT Dana Tabungan dan Asuransi Pegawai Negeri (Persero) Kantor Cabang Manado masih terdapat kekeliruan dalam pencantuman tarif Pajak dan pengelompokkan akun Pajak Penghasilan Pasal 22 sehingga berdampak pada jumlah penyetoran dan pelaporan Pajak Penghasilan Pasal 22.

\subsubsection{Penyetoran Pajak Penghasilan Pasal 22}

Bendaharawan perusahaan PT Dana Tabungan dan Asuransi Pegawai Negeri (Persero) Kantor Cabang Manado ke bank yang sudah ditunjuk oleh pusat, yakni bank BRI untuk menyetor pajak Penghasilan Pasal 22 yang terutang perusahaan dengan membawa berkas hasil rekapan dari total transaksi yang dipungut Pajak Penghasilan Pasal 22. Semenjak diterbitkannya Modul Penerimaan Negara Generasi Kedua (MPN G2), perusahaan sudah tidak lagi menggunakan SSP (Surat Setoran Pajak) manual dalam penyetoran, akan tetapi digantikan dengan menggunakan Surat Setoran Elektronik (Electronic Billing System). Meskipun demikian, hal ini sesuai dengan Peraturan Menteri Keuangan Republik Indonesia Nomor 34/PMK.010/2017 dimana PPh Pasal 22 yang dipungut oleh pihak ketiga, wajib disetorkan oleh pihak ketiga tersebut, dalam hal ini bendaharawan pemerintah ke kas Negara melalui Pos dan Bank persepsi yang ditunjuk oleh Menteri Keuangan, yang disertai dengan SSP yang sudah ditulis nama rekanan serta pemberian tandatangan oleh pemungut pajak dan /atau Bukti Penerimaan Negara yang sudah diisi atas nama rekanan.

Adapun berdasarkan Peraturan Menteri Keuangan Republik Indonesia Nomor 242 tahun 2014 tentang batas waktu penyetoran pajak adalah tanggal 10 bulan berikutnya setelah masa pajak berakhir. Dan PT Dana Tabungan dan Asuransi Pegawai Negeri (Persero) Kantor Cabang Manado telah melaporkan pajak terutangnya tepat waktu yakni sebelum tanggal 10 bulan berikutnya. Akan tetapi karena kesalahan dalam menginput pajak terutang di awal perhitungan, maka perusahaan menyetor lebih bayar pajak terutangnya.

\subsubsection{Pelaporan Pajak Penghasilan Pasal 22}

Tata cara pelaporan Pajak Penghasilan Pasal 22 oleh PT Dana Tabungan dan Asuransi Pegawai Negeri (Persero) Kantor Cabang Manado adalah sebagai berikut :

1. Bendahara perusahaan menyiapkan SPT Masa (manual) Pajak Penghasilan Pasal 22 untuk dilaporkan.

2. Bendahara perusahaan mencetak sendiri SPT sesuai dengan format yang sudah ditentukan.

3. Setelah dicetak, data-data yang ada di SPT diisi dengan benar dan sesuai dengan SSP.

4. SPT kemudian dilaporkan ke Kantor Pelayanan Pajak oleh bendahara perusahaan dengan lampiran SSP dan daftar bukti pungut Pajak Penghasilan Pasal 22 yang sudah ditandatangani oleh kepala bagian kas.

5. Setelah dilakukan pelaporan SPT, dari pihak Kantor Pelayanan Pajak akan memberikan bukti penerimaan surat bahwa dari pihak perusahaan sudah melaporkan Pajak terutangnya.

Pelaporan yang dilakukan PT Dana Tabungan dan Asuransi Pegawai Negeri (Persero) Kantor Cabang Manado sudah tepat waktu sesuai dengan peraturan batas waktu pelaporan yaitu peraturan pasal 10 dan 11 PMK-243/PMK.03/2014. Namun, kesalahan penginputan transaksi membuat PT Dana Tabungan dan Asuransi Pegawai Negeri (Persero) Kantor Cabang Manado harus melakukan pembetulan SPT. Dan sampai pada waktu penelitian yang dilakukan oleh peneliti, pihak perusahaan tidak melakukan pembetulan karena dari bendaharawan perusahaan tidak melakukan prosedur penerbitan Surat Ketetapan Pajak Lebih Bayar (SKPLB) pada masa pajak bulan Februari. 


\section{KESIMPULAN DAN SARAN}

\subsection{Kesimpulan}

PT Dana Tabungan dan Asuransi Pegawai Negeri (Persero) Kantor Cabang Manado adalah Badan Usaha Milik Negara (BUMN) yang dikukuhkan menjadi Pengusaha Kena Pajak. Sehingga terdapat hak dan kewajiban perpajakan yang harus dipenuhi sesuai dengan peraturan perundang-undangan perpajakan yang berlaku. Adapun kesimpulan yang dapat diambil dari hasil analisis pada Bab 4 adalah bahwasannya PT Dana Tabungan dan Asuransi Pegawai Negeri (Persero) Kantor Cabang Manado dalam penerapan PPh Pasal 22 atas pengadaan barang pada tahun 2017, pihak perusahaan menggunakan Peraturan Menteri Keuangan Nomor 34/PMK.010/2017 yaitu pembayaran pengadaan barang diatas Rp 2.000.000 tidak termasuk PPN/PPNBM dan bukan jumlah yang dipecah-pecah. Tata cara perhitungan yang dilakukan oleh bendahara Perusahaan sebagian besar telah sesuai dengan peraturan perpajakan yang beraku, meskipun masih terdapat kekeliruan dalam pemberian tarif PPh Pasal 22. Penyetoran yang dilakukan menggunakan SSP elektronik dan perusahaan telah menyetor dan melaporkan pajak terutangnya tepat waktu tanpa ada keterlambatan sedikitpun. Penerapan PPh Pasal 22 atas pengadaan barang tidak sepenuhnya sesuai dengan Peraturan Menteri Keuangan Nomor 34/PMK.010/2017. Dikatakan demikian, karena dalam pemungutanya masih terdapat kekeliruan dalam menginput akun pajak dan pencantuman tarif yang mengakibatkan lebih bayar pada pajak terutang sehingga berdampak pula pada penyetoran dan pelaporan jumlah pajak terutang. Kelebihan pajak terutang tersebut seharusnya dilakukan pembetulan SPT. Namun dari pihak PT Dana Tabungan dan Asuransi Pegawai Negeri (Persero) Kantor Cabang Manado sampai saat ini tidak melakukan pembetulan SPT atas pajak terutangnya yang lebih bayar dengan melakukan prosedur penerbitan Surat Ketetapan Pajak Lebih Bayar (SKPLB).

\subsection{Saran}

Berdasarkan hasil analisis dan kesimpulan diatas, maka terdapat beberapa saran yang dapat menjadi pertimbangan oleh pihak PT Dana Tabungan dan Asuransi Pegawai Negeri (Persero) Kantor Cabang Manado untuk dapat meningkatkan serta memperbaiki kewajiban perpajakannya, antara lain:

1. Perhatian mengenai ketelitian dalam penulisan tarif dan pengkalisikasian Pajak Penghasilan Pasal 22 sangat diperlukan oleh Bendahara PT Dana Tabungan dan Asuransi Pegawai Negeri (Persero) Kantor Cabang Manado, karena ini akan berpengaruh terhadap jumlah pajak terutang yang akan disetor.

2. Ketika terdapat kurang bayar atau lebih bayar untuk membetulkan SPT pada masa pajak, perhatian oleh bendahara atau pegawai yang berada pada bagian yang sama sangat dibutuhkan sehingga bisa saling mengingatkan jika terdapat pembetulan SPT.

3. Kepada atasan atau kepala cabang PT Dana Tabungan dan Asuransi Pegawai Negeri (Persero) Kantor Cabang Manado, alangkah baiknya para pegawai dibekali pengetahuan tentang dasar-dasar perpajakan yang terdapat diperusahaan. Sehingga pegawai yang menjabat dibagian bendahara sudah mengetahui prosedur perhitungan, penyetoran dan pelaporan pajak terutang sehingga meminimalisir kesalahan lebih atau kurang bayar.

\section{DAFTAR PUSTAKA}

Kementerian Keuangan Republik Indonesia. 2017. Data Penerimaan APBN sampai Tahun2017.https://www.kemenkeu.go.id/apbn2017.Danhttp://www.dataapbn.kemenk eu.go.id/Dataset/Details/1011. 7 Februari 2018 (20:22).

Lubis, I. 2015. Mahir Akuntansi Pajak Terapan Berbasis Standar Akuntansi \& Ketentuan Pajak Terbaru. Andi. Yogyakarta.

Mardiasmo. 2013. Perpajakan. Edisi terbaru. 2018. Andi. Yogyakarta. 
Muljono, D. dan B. Wicaksono. 2009. Akuntansi Pajak Lanjutan. Andi. Yogyakarta.

Peraturan Menteri Keuangan Nomor 34/PMK.010/2017. Pemungutan Pajak Penghasilan Pasal 22 Sehubungan dengan Pembayaran atas Penyerahan Barang dan Kegiatan dibidang Impor atau Kegiatan Usaha dibidang Lain. 27 Mei 2017. Berita Negara Republik Indonesia Tahun 2017 No 361. Jakarta.

Peraturan Menteri Keuangan Pasal 2 PMK-242/PMK.03/2014 dan Pasal 10 dan 11 PMK243/PMK.03/2014. Batas Waktu Penyetoran dan Pelaporan Pajak Untuk SPT Masa. 30 Juli 2015. Direktorat Jendral Pajak Kementrian Keuangan. Jakarta.

Prastowo, Y., A. Priyatna, dan Y. E. Nugraha .2014. Pintar Menghitung Pajak. Raih Asa Sukses,Penebar Swadaya Grup. Jakarta.

Soekrisni, A dan T. Estralita.2013. Akuntansi Perpajakan. Salemba Empat. Jakarta.

Tarigan, M.E.R., J. Morasa, dan I. Elim. 2015. Perhitungan dan Pelaporan Pajak Penghasilan Paal 22 Atas Pengadaan Barang Pada Kantor Badan Perencanaan Pembangunan Penanaman Modal dan Statistik Daerah Kabupaten Bolaang Mongondow. Jurnal Berkala Ilmiah Efisiensi 15(3): 152-167.

Undang-Undang Republik Indonesia No. 16 Tahun 2009. Ketentuan Umum dan Tata Cara Perpajakan. Lembaran Negara Republik Indonesia Tahun 2009 Nomor 4740. Jakarta.

Undang-Undang Republik Indonesia Nomor 36 Tahun 2008. Pajak Penghasilan. Lembaran Negara Republik Indonesia Tahun 2008 Nomor 4893. Jakarta.

Waluyo. 2013. Perpajakan Indonesia. Salemba Empat. Jakarta

Waluyo. 2016. Akuntansi Pajak. Salemba Empat. Jakarta 